\title{
COGITARE ENFERMAGEM: REALIZAÇÕES E DESAFIOS
}

Elaine Drehmer de Almeida Cruz ${ }^{1}$

A Cogitare Enfermagem é publicação que traz em seu bojo não só a transmissão do já conhecido; inova, reflete e critica para a formação de referências em tecnologia e ciência e constitui espaço de ensino. Tem a preocupação constante com o desenvolvimento de sua capacidade de avaliação e renovação, considerada por seu corpo editorial como fundamental à produção científica, respondendo as demandas da sociedade com rigor científico e originalidade.

Tomado como referência este norteador, a Revista desenvolve, desde sua primeira edição em 1996, reformulações quanto à organização interna e definições de políticas editoriais. Passou de aproximadamente 20 artigos publicados em dois números anuais para 100 artigos em quatro números. A partir de 2009 assumiu e vem cumprindo rigorosa periodicidade na publicação de 25 artigos e um editorial por número. Desde 2012 publica 20 artigos originais de pesquisa em cada exemplar, divulgados na versão impressa e na versão eletrônica, com acesso aberto.

Em relação à classificação, em 2012 a Cogitare Enfermagem passou de B3 para B2, de acordo com a estratificação da qualidade da produção intelectual no Qualis Periódicos da Coordenação de Aperfeiçoamento de Pessoal de Nível Superior - CAPES, Área de Enfermagem. Diante da consistência e avanços editoriais, a mudança de estrato resultou em aumento significativo de manuscritos submetidos à Revista no corrente ano.

O rigor científico, relativo também à observação aos princípios éticos, tem sido de longa data uma preocupação. Conselho de editoração, editores e consultores estão atentos à necessidade de medidas avaliativas e rigorosas para a identificação de plágio, autoplágio e falsificação de dados. Com esta realidade à porta das revistas científicas, a Cogitare Enfermagem realizou o I e II Encontros Universitários de Editoração Científica, nos anos 2010 e 2012, respectivamente, financiados pela CAPES e Conselho Federal de Enfermagem. A ética na publicação e estratégias para seu aprimoramento foram temas centrais, amplamente discutidos por especialistas, pesquisadores e alunos de pós-graduação e de graduação. Todos foram unânimes quanto à relevância e compromisso em promover conhecimentos, habilidades e atitudes no âmbito da investigação científica, e sua publicação com rigor científico e ético.

Em continuidade à política de inovação novos desafios e ações são traçados. Em 2013 os objetivos estão direcionados para estratégias e critérios de aprimoramento na seleção dos manuscritos; otimização do tempo despendido entre pré-análise, avaliação por consultores e resposta aos autores, e entre a submissão e a publicação. Também modificações nas categorias e formato dos artigos publicados estão previstos.

Considerando a tendência mundial de publicação exclusiva na versão eletrônica será reduzido, progressivamente, o número de exemplares na versão impressa, mantendo-os suficientes para atender aos acordos de permuta firmados. A ampliação das bases de dados contribuirá para a visibilidade da Cogitare Enfermagem, assim como da Enfermagem brasileira.

Vencer os desafios impostos aos periódicos na atualidade, com destaque à cientificidade, internacionalização, profissionalização e visibilidade, é meta da Revista. O trabalho coletivo e participativo da equipe editorial e dos consultores ad hoc tem a finalidade de reiterar o compromisso social assumido por seus idealizadores no processo de editoração e se reflete na missão da Cogitare Enfermagem.

${ }^{1}$ Enfermeira. Doutora em Enfermagem. Editora da Cogitare Enfermagem. Professora do Curso de Graduação e dos Programas de PósGraduação em Enfermagem da Universidade Federal do Paraná. Membro do Grupo de Estudos Multidisciplinar em Saúde do Adulto e Idoso - GEMSA. 


\title{
COGITARE ENFERMAGEM: ACCOMPLISHMENTS AND CHALLENGES
}

\author{
Elaine Drehmer de Almeida Cruz ${ }^{1}$
}

Cogitare Enfermagem is a publication that brings not only the transmission of what is already known; it innovates, reflects and criticizes for the creation of benchmarks in technology and science, and constitutes an area of education. There is a constant concern for the development of its ability for evaluation and renewal, considered by the editorial body to be fundamental to scientific production, responding to society's requirements with scientific rigor and originality.

Taking this guiding principle as a benchmark, the Magazine has developed, since its first edition in 1996, adaptations for internal organization and definitions of editorial policies. It has gone from some twenty articles published in two issues per year, to 100 articles in four issues. From 2009 on, it has taken on and met a rigorous regularity in the publication of 25 articles and one editorial per issue. As of this year it has published 20 articles of original research in each issue, both in print and in open-access electronic format.

In relation to classification, in 2012 Cogitare Enfermagem moved from B3 to B2, in line with the qualitative rating of the intellectual production in the Qualis journals of the Coordination for the Improvement of Higher Education Personnel (CAPES), Nursing Area. Given the consistency and editorial advances, the change of rating resulted in a significant increase in the number of manuscripts submitted to the Magazine this year.

The scientific rigor, relative also to the observation of ethical principles, is a long-standing concern. The Editorial Board, editors and consultants are alert to the need for rigorous evaluative measures for the identification of plagiarism, self-plagiarism and falsification of data. In the face of this reality at the door of scientific magazines, in 2010 and 2012 Cogitare Enfermagem held, respectively, the I and II University Conferences on Scientific Publishing, financed by CAPES and the Federal Council of Nursing. The central themes were ethics in publishing and strategies for its improvement, which were widely discussed by specialists, researchers, and students from undergraduate and postgraduate courses, who were unanimous as to the relevancy and commitment to promoting knowledge, skills and attitudes in the scope of scientific investigation, and its publication with scientific and ethical rigor.

In continuity with the policy of innovation, new challenges and actions are planned. In 2013, the objectives are directed towards strategies and criteria for improving the selection of manuscripts and optimization of the time spent in pre-analysis, evaluation by consultants, responding to the authors, and between submission and publication. In addition, it is foreseen that there will be changes in the categories and format of the articles published.

Considering the worldwide tendency for publication exclusively in electronic format, the number of printed issues will be progressively reduced, maintaining them sufficient to meet swap agreements entered into. The enlargement of the databases will contribute both to Cogitare Enfermagem's visibility, and that of Nursing in Brazil.

The Magazine's goal is to overcome the challenges presently imposed on journals with emphasis on scientific endorsement, professionalization and visibility. The collective and participative work of the editorial team and consultants ad hoc has the purpose of reaffirming in the editorial process the social commitment taken on by the Magazine's originators - and is reflected in Cogitare Enfermagem's mission.

\footnotetext{
${ }^{1}$ Nurse. Doctorate in Nursing. Editor of Cogitare Enfermagem. Professor of the Undergraduate Course and in the programs of the Postgraduate in Nursing Programs at the Federal University of Paraná. Member of the Multidisciplinary Studies Group in the Health of Adults and Older Adults - GEMSA.
}

Cogitare Enferm. 2012 Out/Dez; 17(4):617-9 


\section{COGITARE ENFERMAGEM: REALIZACIONES Y DESAFÍOS}

Elaine Drehmer de Almeida Cruz

La revista Cogitare Enfermagem es una publicación cuyo objetivo mayor no es solamente transmitir lo que ya es conocido. Es su misión innovar, reflexionar y criticar a fin de traer referencias en tecnología y ciencia, constituyéndose también en un espacio de enseñanza. Tiene la preocupación constante con el desarrollo de su capacidad de evaluación y renovación, considerada por su cuerpo editorial como fundamental a la producción científica, contestando a las demandas de la sociedad con rigor científico y originalidad.

Partiendo de esta referencia como un norteador, la Revista desarrolla, desde su primera edición en 1996, reformulaciones acerca de la organización interna y definiciones de políticas editoriales. De aproximadamente 20 artículos publicados en dos números anuales, pasó para 100 artículos en cuatro números. A partir de 2009 asumió y viene cumpliendo rigurosa periodicidad en las publicaciones de 25 artículos y un editorial por número. Desde 2012 publica 20 artículos originales de investigación en cada ejemplar, divulgados en la versión impresa y en la versión electrónica, con acceso libre.

Acerca de la clasificación, en 2012 Cogitare Enfermagem evolucinó de B3 para B2, de acuerdo con la estratificación da calidad de la produción intelectual en el Qualis Periódicos da Coordenação de Aperfeiçoamento de Pessoal de Nível Superior - CAPES, Área de Enfermería. Delante de la consistencia y de los avances editoriales, el cambio de estrato ha resultado en aumento significativo de manuscritos sometidos a la Revista este año.

El rigor científico, que se refiere también a la observación a los principios éticos, es una preocupación desde siempre. Consejo de editoración, editores y consultores están atentos a la necesidad de medidas evaluativas y rígidas para la identificación de plagio, autoplagio y falsificación de datos. A causa de esta realidad que puede atingir revistas científicas, Cogitare Enfermagem realizóu el I y II Encuentros Universitarios de Editoración Científica, en los años de 2010 y 2012, respectivamente, financiados por CAPES y Conselho Federal de Enfermagem. La ética en la publicación y estrategias para su perfeccionamiento fueron temas centrales, muy discutidos por especialistas, investigadores y alumnos de posgrado y graduación. Todos fueron unánimes cuanto a la relevancia y compromiso en promover conocimientos, habilidades y actitudes en el ámbito de la investigación científica y sua publicación con rigor científico y ético.

En continuidad a la política de innovación, son delineados nuevos desafíos y acciones. En 2013, los objetivos se vuelven a estrategias y criterios de perfeccionamiento en la selección de los manuscritos; otimización del tiempo utilizado entre el preanálisis, la evaluación por consultores y respuesta a los autores, y entre la sumisión y la publicación. Todavía están previstos cambios en las categorías y en el formato de los artículos publicados.

Considerando la tendencia mundial de publicación exclusiva en la versión electrónica, será reducido, progresivamente, el número de ejemplares en la versión impresa, manteniéndola en número suficiente para atender a los acuerdos de permuta firmados. La ampliación de las bases de datos contribuirá para la visibilidad de Cogitare Enfermagem, así como de la Enfermería brasileña.

Vencer los desafíos impuestos a los periódicos en la actualidad con destaque a la cientificidad, internacionalización, profesionalización y visibilidad es meta de la Revista. El trabajo colectivo y participativo del equipo editorial y de los consultores ad hoc tiene la finalidad de reafirmar el compromiso social asumido por los idealizadores en el proceso de editoración y se reflecta en la misión de Cogitare Enfermagem.

${ }^{1}$ Enfermera. Doctora en Enfermería. Editora de Cogitare Enfermagem. Profesora del Curso de Graduación y de los Programas de Posgrado en Enfermería de la Universidade Federal do Paraná. Miembro del Grupo de Estudos Multidisciplinar em Saúde do Adulto e Idoso - GEMSA. 